\title{
The Partial Protective Effect of the Hydroxyl Radical Scavenger Dimethyl Urea on Streptozotocin-Induced Diabetes in the Mouse in Vivo and in Vitro
}

\author{
S. Sandler and A. Andersson \\ Department of Medical Cell Biology, University of Uppsala, Uppsala, Sweden
}

\begin{abstract}
Summary. The protective effect on streptozotocin-induced diabetes of dimethyl urea, a hydroxyl radical scavenger, has been evaluated in vivo and in vitro. Pretreatment with dimethyl urea before a single diabetogenic dose of streptozotocin partially protected NMRI mice from hyperglycaemia, whereas the serum glucose of C57BL/KsJ mice increased during week 2 of observation. When the pancreases of these latter mice were examined histologically, insulitis was found in 15 out of 22 animals. The protective effect of dimethyl urea in the NMRI mice was not due to short-term hyperglycaemia induced by the drug, since pretreatment with glucose did not protect from streptozo-
\end{abstract}

tocin but potentiated its diabetogenic effect. Dimethyl urea reduced the inhibition caused by streptozotocin on proinsulin biosynthesis of NMRI islets in vitro. It is suggested that streptozotocin-induced diabetes in mice may involve generation of hydroxyl radicals which are toxic to islet $B$ cells. If this immediate cytotoxicity is reduced by a scavenger, a more slowly developing hyperglycaemia and an accompanying insulitis may occur in particularly susceptible animals.

Key words: Streptozotocin, dimethyl urea, NMRI mice, C57BL/KsJ mice, proinsulin biosynthesis, insulitis.
The mechanisms by which alloxan and streptozotocin (SZ) exert their diabetogenic actions on the pancreatic B cells are still not clearly understood, but recent evidence suggests that their toxicity may be mediated by free oxygen radicals. The radicals are generated in a sequential process during oxygen reduction, finally resulting in the highly reactive and noxious hydroxyl radical [1]. Cohen and Heikkila [2] have demonstrated that such radicals can be generated in a cell free system from dialuric acid, the reduced form of alloxan. It has been demonstrated also, both in vivo and in vitro, that substances which are known to scavenge free radicals either directly or enzymically, can prevent the cytotoxic effects of alloxan on islet B cells [3-8].

Evidence in support of a free radical mediated toxicity by SZ is sparse. Slonim et al. [9] demonstrated free radical production by SZ in vitro in rat pancreatic microsomes and Robbins et al. [10] and Marklund and Grankvist [11] have shown that the superoxide anion scavenging enzyme, superoxide dismutase, partially protects the islets when administrated before $\mathrm{SZ}$ in vivo. On the other hand, Gold et al. [12] were unable to demonstrate any protection from SZ action by superoxide dismutase in vitro measuring islet insulin release. In the present study we examined the effect of a hydroxyl radical scavenger, dimethyl urea (DMU), on SZ-induced hyperglycaemia in vivo and on SZ-inhibited islet proinsulin biosynthesis in vitro. This particular scavenger was chosen since it has been shown to protect against alloxan-induced diabetes $[4,5,8]$ and to be a potent hydroxyl scavenger in vitro [13].

\section{Materials and Methods}

\begin{abstract}
Animals
Adult male NMRI mice (Anticimex, Sollentuna, Sweden) and inbred $\mathrm{C} 57 \mathrm{BL} / \mathrm{K} \mathrm{J}$ mice originally obtained from Jackson Laboratories, Bar Harbor, Maine, USA, aged 8-12 wecks, were used. The animals were allowed free access to water and laboratory chow (Ewos-Anticimex, Type R3; Ewos, Södertälje, Sweden) during the experimental period.
\end{abstract}

\section{Chemicals}

Streptozotocin (lot 60,273-3 and 5) was a gift of Dr. W.E. Dulin, Upjohn Company, Kalamazoo, Michigan, USA. Collagenase was from Worthington Biochemicals, Freehold, New Jersey, USA and bovine albumin (fraction V) was from Miles Laboratories, Slough, Bucks, UK. Hanks' solution was supplied by Statens Bakteriologiska Laboratorium, Stockholm, Sweden. $\mathrm{L}-\left[4,5{ }^{3} \mathrm{H}\right]$ leucine was obtained from Amersham International, Bucks, UK. CNBr-activated Sepharose 4B was from Pharmacia Fine Chemicals, Uppsala, Sweden. Econofluor was purchased from New England Nuclear, Boston, Massachusetts, USA 
Table 1. Serum glucose concentrations in NMRI and C57BL/KsJ mice pretreated with either dimethyl urea or saline before a single dose of streptozotocin

\begin{tabular}{|c|c|c|c|c|}
\hline \multirow{3}{*}{$\frac{\text { Mouse strain }}{\text { Treatment }}$} & \multicolumn{4}{|c|}{ Serum glucose concentrations ( $\mathrm{mmol} / \mathrm{l}$ ) } \\
\hline & \multicolumn{2}{|l|}{ NMRI } & \multicolumn{2}{|l|}{ C57BL/KsJ } \\
\hline & $\begin{array}{l}\text { Saline + SZ } \\
(n=15)\end{array}$ & $\begin{array}{l}\mathrm{DMU}+\mathrm{SZ} \\
(n=15)\end{array}$ & $\begin{array}{l}\text { Saline }+\mathrm{SZ} \\
(n=18)\end{array}$ & $\begin{array}{l}\mathrm{DMU}+\mathrm{SZ} \\
(n=22)\end{array}$ \\
\hline Before pretreatment & $8.5 \pm 0.5$ & $8.9 \pm 0.5$ & $8.6 \pm 0.3$ & $8.9 \pm 0.2$ \\
\hline 30 min after pretreatment & $10.6 \pm 0.2$ & $16.3 \pm 0.8^{c}$ & $9.4 \pm 0.4$ & $11.7 \pm 0.6^{\mathrm{c}}$ \\
\hline 3 days after $S Z$ & $17.2 \pm 2.4$ & $11.0 \pm 0.9^{\mathrm{a}}$ & $19.7 \pm 2.2$ & $10.0 \pm 0.9^{\mathrm{a}}$ \\
\hline
\end{tabular}

Results expressed as mean \pm SEM. Male NMRI or C57BL/KsJ mice were given DMU $(4 \mathrm{~g} / \mathrm{kg}$ body-weight, IP) or an equal volume of saline $(9 \mathrm{~g} / \mathrm{l})$ $30 \mathrm{~min}$ before SZ (160 mg/ $\mathrm{kg}$ body-weight, IV). ${ }^{a} p<0.05,{ }^{\mathrm{b}} p<0.01$ and ${ }^{\mathrm{c}} p<0.001$ : significance of difference for each strain between the DMU and saline pretreated groups

and Soluene from Packard Instruments, Downers Grove, Illinois, USA. Hepes and 1,1-dimethyl urea were supplied by Sigma Chemicals, St Louis, Missouri, USA. Other chemicals of analytical grade were provided by E. Merck, Darmstadt, FRG.

\section{Experiments in Vivo}

NMRI or C57BL/KsJ mice were pretreated IP either with DMU at a dosage of $4 \mathrm{~g} / \mathrm{kg}$ body-weight, or with an equal volume of saline $(9 \mathrm{~g} / 1$, $500 \mu \mathrm{l}), 30 \mathrm{~min}$ before IV administration of a diabetogenic dose of SZ $(160 \mathrm{mg} / \mathrm{kg}$ body-weight). In a separate series of experiments, NMRI mice were given glucose solution $(300 \mathrm{~g} / 1,250 \mu \mathrm{l}) \mathrm{IP} 30 \mathrm{~min}$ before $\mathrm{SZ}$; control mice received saline $(250 \mu)$ IP. Blood samples were collected by retro-orbital sinus puncture and assayed using an automated glucose analyser (Beckman Instruments, Fullerton, California, USA). Serum glucose samples were taken without anaesthesia before pretreatment, 30 min after pretreatment at the time of SZ administration and on days 3,7 and 14 , the mice being killed after the last sampling.

The mice were killed by cervical distension and the pancreases were removed quickly, fixed in Bouin's solution and embedded in paraffin. Sections ( $7 \mu \mathrm{m}$ thick) were cut, stained with hematoxylin-eosin and examined on a blind basis for the general histology and especially for the occurrence of round cell infiltration of the islets, i. e. insulitis.

\section{Experiments in Vitro}

NMRI mice were used exclusively in this series of experiments. Pancreatic islets were isolated by collagenase digestion [14]. The islets were incubated in groups of 50 in a bicarbonate buffer $(1 \mathrm{ml})$ [15] supplemented with Hepes $(10 \mathrm{mmol} / \mathrm{l})$, albumin $(2 \mathrm{mg} / \mathrm{ml})$ and glucose $(5.5 \mathrm{mmol} / \mathrm{l})$. SZ was dissolved in cold citrate buffer $(\mathrm{pH} 4.5)$ immediately before use and 5-10 $\mu \mathrm{l}$ of this solution were added to the islets to obtain the required $\mathrm{SZ}$ concentrations. The incubations were performed in air at room temperature $(30 \mathrm{~min})$ and terminated by addition of the bicarbonate buffered medium $(3 \mathrm{ml})$. In each experiment, control islets were treated with citrate solution $(5-10 \mu l)$. To test the effects of DMU, it was added to the albumin and Hepes supplemented bicarbonate buffer medium (final concentration $6 \mathrm{mg} / \mathrm{ml}$ ) and preincubated with islets for $30 \mathrm{~min}$ at $37^{\circ} \mathrm{C}$ to allow penetration of the cells before exposure to $\mathrm{SZ}$.

Immediately after the SZ incubations, the islets in two groups of 20 from each incubation vial were transferred to the same bicarbonate buffered medium as above $(100 \mu \mathrm{l})$ containing $\mathrm{L}-\left[4,5-{ }^{3} \mathrm{H}\right] \mathrm{leucine}$ $(50 \mu \mathrm{Ci} / \mathrm{ml})$, albumin $(2 \mathrm{mg} / \mathrm{ml})$ and glucose $(16.7 \mathrm{mmol} / \mathrm{l})$. After $2 \mathrm{~h}$ incubation at $37^{\circ} \mathrm{C}$ (air $+5 \% \mathrm{CO}_{2}$ ), the islets were washed and sonicated for $10 \mathrm{~s}$ in redistilled water $(200 \mu \mathrm{l})$. A fraction of the aqueous homogenate was subsequently incubated with antibovine insulin serum coupled to Sepharose $4 \mathrm{~B}$ beads to separate labelled proinsulin from other labelled islet proteins [16]. Control values obtained by incubation of the same homogenate with normal guinea-pig serum proteins coupled to Sepharose beads were subtracted from the experimental values. Soluene $(0.5 \mathrm{ml})$ and Econofluor $(5 \mathrm{ml})$ were added to each sample and the antibody-bound and trichloroacetic acid precipitable radioactivity (total protein biosynthesis) was determined in a liquid scintillation spectrometer (Packard Tri-Carb, model 3255). The corresponding mean c.p.m. values per 20 islets from each experiment were calculated. The rate of proinsulin biosynthesis of the experimental group was expressed as a percentage of the control group.

\section{Statistical Analyses}

Groups of data were compared using the unpaired Student's t-test, or Fisher's exact test for $2 \times 2$ tables [17].

\section{Results}

\section{Effects of Dimethyl Urea on the Diabetogenic Effects of Streptozotocin in Vivo}

There was a continuous increase in the serum glucose concentration of NMRI mice given saline before SZ administration (Table 1). Thus, 12 out of 15 mice were hyperglycaemic with a serum glucose $>12.5 \mathrm{mmol} / 1$ after 2 weeks. In contrast, only five of the 15 DMU-pretreated NMRI mice were hyperglycaemic 2 weeks following SZ injection. At all times after the SZ injection serum glucose was lower in the DMU-pretreated group. DMU in itself produced a significant serum glucose elevation 30 min post-injection $(p<0.001)$. i. e. at the time when SZ was administered.

When the same experiments were performed in C57BL/KsJ mice, DMU protected against hyperglycaemia during the first 3 days (Table 1 ). After 2 weeks the mean serum glucose concentration had increased markedly but it was still below that of the SZ treated controls. Three DMU pretreated C57BL/KsJ mice and none of the control animals had a serum glucose $<12.5 \mathrm{mmol} / 1$ at the time of death. It is worthy of note that the C57BL/ KsJ mice had markedly higher serum glucose concentrations than the NMRI mice 2 weeks after the SZ injection and the difference between the control groups at this time was highly significant $(p<0.001)$. 
The results of histological examination of the pancreases are summarized in Table 2. Fifteen of the 22 $\mathrm{C} 57 \mathrm{BL} / \mathrm{KsJ}$ mice given DMU before SZ exhibited pancreatic insulitis (Fig. 1; Table 2, class C), which was observed in only one of the 18 control animals. In some of the C57BL/KsJ mice treated with $\mathrm{DMU}+\mathrm{SZ}$, areas of inflammatory reactions were observed in the exocrine pancreas with a pronounced connective tissue proliferation containing a pleomorphic mass of cells (Fig. 2), similar to that which we have observed previously in multiSZ-treated C57BL/KsJ mice [18].

Ten of the control NMRI mice had only a few small islets containing a majority of pycnotic cells (Table 2 , class D), whereas only one of the DMU-treated NMRI mice displayed a similar islet morphology. In separate control experiments both C57BL/KsJ and NMRI mice were given DMU only. No long-term effects on the pancreatic morphology or serum glucose concentrations
Table 2. Pancreatic islet morphology 14 days after a single dose of streptozotocin in C57BL/KsJ and NMRI mice pretreated with either dimethyl urea or saline

\begin{tabular}{lcccc}
\hline Islet morphology & A & B & C & D \\
\hline C57BL $/$ Ks J mice & & & & \\
DMU + SZ $(n=22)$ & 4 & 2 & $15^{\mathrm{a}}$ & 1 \\
Saline + SZ $(n=18)$ & 0 & 3 & 1 & 14 \\
NMRImice & & & & \\
DMU + SZ $(n=15)$ & 8 & 5 & 1 & $1^{\mathrm{a}}$ \\
Saline + SZ $(n=15)$ & 4 & 1 & 0 & 10 \\
\hline
\end{tabular}

The islet morphology of each animal was evaluated according to four arbitrary classes by light microscopy. A: Normal islet morphology; B: Essentially normal islet appearance, but with some mononuclear cell infiltration especially in the peri-insulinar tissue; $\mathrm{C}$ : Heavy infiltration of mononuclear cells into a large number of islets (Fig. 1); D: 'Diabetic' appearance with only a few, small islets and islets displaying vast cellular disarray and pycnotic nuclei. The different groups were compared by Fisher's exact test for $2 \times 2$ tables [17]. ${ }^{a} p<0.001 \mathrm{com}-$ pared with the saline treated control group
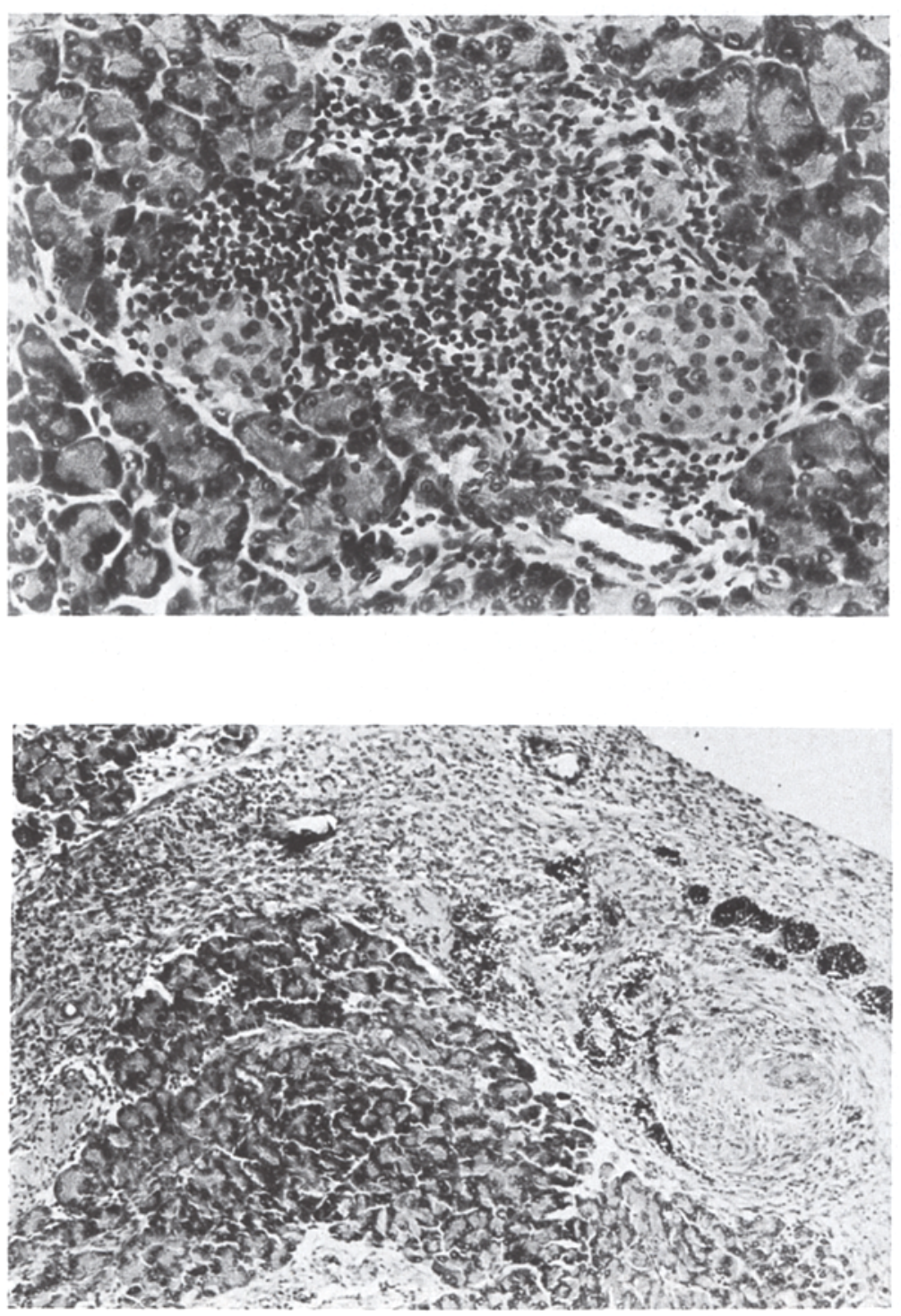

Fig. 1. Pancreatic islets of a C57BL/KsJ mouse treated with dimethyl urea and streptozotocin showing severe round cell infiltration. The serum glucose after 14 days (at death) was $16.5 \mathrm{mmol} / 1$. Hematoxylin and $\operatorname{eosin}(\times 250)$
Fig. 2. Pancreas of a C57BL/KsJ mouse treated with dimethyl urea and streptozotocin, showing an area of proliferative connective tissue. Hematoxylin and eosin $(x 100)$ 
Table 3. Rates of proinsulin biosynthesis in islets exposed to streptozotocin and dimethyl urea in vitro for $30 \mathrm{~min}$ at $5.5 \mathrm{mmol} / 1$ glucose

\begin{tabular}{llll}
\hline $\begin{array}{l}\mathrm{SZ} \\
(\mathrm{mmol} / \mathrm{l})\end{array}$ & $\begin{array}{l}\text { DMU } \\
(\mathrm{mg} / \mathrm{ml})\end{array}$ & $\begin{array}{l}\text { Proinsulin biosynthesis } \\
\text { (\% of control) }\end{array}$ & $\begin{array}{l}\text { No of } \\
\text { experiments }\end{array}$ \\
\hline 0.55 & 0 & $93.2 \pm 5.4$ & 5 \\
1.1 & 0 & $74.9 \pm 7.4^{\mathrm{a}}$ & 7 \\
2.2 & 0 & $60.2 \pm 5.6^{\mathrm{b}}$ & $\mathrm{c}$ \\
2.2 & 6 & $86.5 \pm 4.9^{\mathrm{a}}$ & 17 \\
4.4 & 0 & $34.3 \pm 2.7^{\mathrm{b}} 7^{\mathrm{d}}$ & 11 \\
4.4 & 6 & $55.5 \pm 5.1^{\mathrm{b}}$ & 38 \\
\hline
\end{tabular}

Results expressed as mean \pm SEM. Proinsulin biosynthesis was estimated by measuring the incorporation of $\mathrm{L}-\left[4,5-{ }^{3} \mathrm{H}\right]$ leucine into the proinsulin fraction of islets incubated for $2 \mathrm{~h}$ in a medium supplemented with $16.7 \mathrm{mmol} / 1$ glucose. The mean c. p. $\mathrm{m}$. values per 20 islets for each experimental group were calculated. The data were expressed as the percentage proinsulin biosynthesis of the experimental group compared with the control group, which was not exposed to SZ. The statistical significance of the difference between SZ-exposed and non-exposed control islets was tested by means of a paired t-test: ${ }^{\mathrm{a}} p<0.05$ and ${ }^{\mathrm{b}} p<0.001$. An unpaired $\mathrm{t}$-test was used for calculating the statistical significance of the difference obtained by the addition of DMU to islets: ${ }^{\mathrm{c}} p<0.01$ and ${ }^{\mathrm{d}} p<0.001$

were observed during the 2-week follow-up period (results not shown).

In order to test the hypothesis that the DMU-induced acute elevation of the serum glucose (Table 1) contributed to the protective effect against SZ, NMRI mice were pretreated with glucose $30 \mathrm{~min}$ before the SZ injection $(160 \mathrm{mg} / \mathrm{kg}$ body-weight, IV). Such mice developed a more marked hyperglycaemia 3 days after the SZ injection than the corresponding control group pretreated with saline $(21.4 \pm 2.4$ and $14.2 \pm 1.7 \mathrm{mmol} / 1$ glucose, respectively; $p<0.05 ; n=18$ for both groups). On days 7 and 14 no significant differences were observed in the serum glucose of the two groups of mice. Four of the 18 mice pretreated with glucose died before the end of the 2-week observation period. The islets of all but one of these surviving mice were very small and disintegrated (corresponding to class D, Table 2).

\section{Effects of Dimethyl Urea in Vitro}

A dose-dependent inhibition of glucose-stimulated proinsulin biosynthesis was observed in islets exposed to SZ for $30 \mathrm{~min}$ in vitro (Table 3 ). No significant depression of the biosynthetic rate could be demonstrated at $0.55 \mathrm{mmol} / 1 \mathrm{SZ}$, but it was significant at all higher concentrations. Moreover, the percentage contribution of proinsulin to the total protein biosynthesis showed a similar dose-dependent decrease (data not shown). The SZ inhibited proinsulin biosynthesis was partially normalised by DMU and a significant protection was found both at 2.2 and $4.4 \mathrm{mmol} / 1 \mathrm{SZ}$.

\section{Discussion}

In the present investigation dimethyl urea was found to protect partially NMRI mice against the hyperglycaemic effect of streptozotocin. It seems plausible that the pro- tective effect of DMU in vivo is not due to its short-lasting hyperglycaemic effect, which is well known to protect against alloxan action $[19,20]$. We found, in contrast, an enhancing effect of glucose on the SZ action, which is in agreement with the results of Brodsky and Logothetopoulos [21] on C57BL/6J mice. Dulin and Wyse [22] and Ganda et al. [23] likewise were unable to protect rats by administration of glucose prior to SZ. The fact that DMU partially prevented the SZ-induced depression of proinsulin biosynthesis in vitro further supports the view that the protection of DMU in vivo is not due to its hyperglycaemic effect.

When C57BL/KsJ mice were given DMU and a single diabetogenic dose of SZ, hyperglycaemia developed more slowly than in the control animals and was accompanied by insulitis in 15 of the 22 animals. Like and Rossini have shown that $\mathrm{C} 57 \mathrm{BL} / \mathrm{KsJ}$ mice receiving five sub-diabetogenic doses of SZ developed insulitis and a gradual hyperglycaemia [24]. These authors have suggested that this treatment in susceptible mouse strains, may induce a direct B cell cytotoxicity and in combination with virus induction within the $\mathrm{B}$ cells may initiate a cell-mediated auto-immune reaction [25]. It could be speculated that DMU when given to C57BL/ $\mathrm{KsJ}$ mice before a high dose of SZ, reduces the immediate $B$ cell cytotoxicity and a gradual hyperglycaemia develops, similar to that of the multi-SZ model. The pathogenetic significance of insulitis for hyperglycaemia in these animals may, however, be doubtful as suggested by Leiter [26].

The chemical reaction by which SZ causes B cell cytotoxicity and the nature of hydroxyl radical involvment remains obscure. Recently, Yamamoto and Okamoto [27] demonstrated an increased activity of polyadenosine diphosphoribose (poly (ADP-rib)) synthetase, an enzyme participating in DNA-repair, in nuclei from rat pancreatic islets exposed to $\mathrm{SZ}$ in vitro. This enzyme uses NAD as a substrate, which is concordant with the documented observation that SZ depletes the NAD content of pancreatic islets [28-29]. It has been demonstrated that enzymically generated oxygen radicals in vitro can cause DNA single strand breaks [30], which presumably activates the enzyme. Furthermore, Skidmore et al. [31] have observed similar effects on NAD concentrations and poly(ADP-rib) synthetase activity in mouse leukaemia cells after methylnitrosourea (the aglucone moiety of SZ) and $\gamma$-radiation treatment. The latter is well known to produce free radicals. In support of such a mechanism, we have found that DMU inhibits the NAD depletion of mouse pancreatic islets exposed to SZ in vitro [32].

Acknowledgements. We thank Professor C. Hellerström for valuable advice during the course of this work and Dr. U. Eriksson for valuable statistical help. We are grateful to A.-B.Andersson, C. Bittkowski, M. Engkvist, E. Forsbeck and A. Nordin for excellent technical assistance and K. Claesson and A. Snellman for typing the manuscript. This work was supported by grants from the Swedish Medical Research Council $(12 \times-109)$, the Swedish Diabetes Association and the Medical Faculty of the University of Uppsala. 


\section{References}

1. Fridovich I (1978) The biology of oxygen radicals. Science 201: $875-880$

2. Cohen G, Heikkila RE (1974) The generation of hydrogen peroxide, superoxide radical and hydroxyl radicals by 6-hydroxy-dopamine, dialuric acid and related cytotoxic agents. J Biol Chem 249: 2447-2452

3. Heikkila RE, Winston B, Cohen G (1976) Alloxan-induced diabetes - Evidence for hydroxyl radical as a cytotoxic intermediate. Biochemical Pharmacol 25: 1085-1092

4. Heikkila RE, Cabbat FS (1978) Protection against alloxan-induced diabetes in mice by the hydroxyl radical scavenger dimethylurea. Europ J Pharmacol 52: 57-60

5. Tibaldi J, Benjamin J, Cabbat FS, Heikkila RE (1979) Protection against alloxan-induced diabetes by various urea derivates: Relationship between protective effects and reactivity with the hydroxyl radical. J Pharmacol Exptl Therap 211: 415-418

6. Grankvist K, Marklund S, Sehlin J, Täljedal I-B (1979) Superoxide dismutase, catalase and scavengers of hydroxyl radicals protect against the toxic action of alloxan on pancreatic islet cells in vitro. Biochem J 182: 17-25

7. Fischer LJ, Hamburger SA (1980) Inhibition of alloxan action in isolated pancreatic islets by superoxide dismutase, catalase and a metal chelator. Diabetes 29:213-216

8. Fischer LJ, Hamburger SA (1980) Dimethylurea: A radical scavenger that protects isolated pancreatic islets from the effects of alloxan and dihydroxyfumarate exposure. Life Science 26: 1405-1409

9. Slonim AE, Surber MJ, Cameron MR, Burr IM (1980) Mechanism for chemically induced diabetes: Evidence for oxidant action and free radical production. Diabetes 29 (Suppl 2): 129 (Abstract)

10. Robbins MJ, Sharp RA, Slonim AE, Burr IM (1980) Protection against streptozotocin-induced diabetes by superoxide dismutase. Diabetologia 18:55-58

11. Marklund S, Grankvist K (1981) Polyethyleneglycol-superoxide (PEG-SOD) protect against streptozotocin-induced diabetes in mice. Acta Endocrinol 98 (Suppl 245): 43 (Abstract)

12. Gold G, Manning M, Heldt A Nowlain R, Pettit JR, Grodsky GM (1981) Diabetes induced with multiple subdiabetogenic doses of streptozotocin. Lack of production by exogenous superoxide dismutase. Diabetes 30:634-638

13. Miller JS, Cornwell DG (1978) The role of cryoprotective agents as hydroxyl radical scavengers. Cryobiology 15:585-588

14. Howell SL, Taylor KW (1968) Potassium ions and the secretion of insulin by islets of Langerhans incubated in vitro. Biochem $\mathrm{J} 108$ : $17-24$

15. Krebs HA, Henseleit K (1932) Untersuchungen über die Harnstoffbildung im Tieferkörper, Hoppe-Seylers Z Physiol Chem 210: $33-66$

16. Berne C (1975) Anti-insulin serum coupled to Sepharose 4B as a tool for the investigation of insulin biosynthesis in the B-cells of obese hyperglycemic mice. Endocrinology 97: 1241-1247

17. Ostle B (1963) Statistics in research, 2nd edr. Ames, The Iowa State University Press
18. Sandler S, Andersson A (1981) Islet implantation into mice with pancreatic insulitis. Acta Path Microbiol Scand Sect A 89: 107-112

19. Bhattacharya $G$ (1954) On the protection against alloxan diabetes by hexoses. Science 120:841-843

20. Scheynius A, Täljedal I-B (1971) On the mechanism of glucose protection against alloxan toxicity. Diabetologia 7:252-255

21. Brodsky G, Logothetopoulos J (1969) Streptozotocin diabetes in the mouse and guinea pig. Diabetes 18: 606-611

22. Dulin WE, Wyse BM (1969) Studies on the ability of compounds to block the diabetogenic activity of streptozotocin. Diabetes 18 : $459-466$

23. Ganda OP, Rossini AA, Like AA (1976) Studies on streptozotocin diabetes. Diabetes 25: 595-603

24. Rossine AA, Appel MC, Williams RM, Like AA (1977) Genetic influence of the streptozotocin-induced insulitis and hyperglycemia. Diabetes 26:916-920

25. Appel MC, Rossini AA, Williams RM, Like AA(1978) Viral studies in streptozotocin-induced pancreatic insulitis. Diabetologia 15: $327-336$

26. Leiter EH (1982) Multiple low-dose streptozotocin-induced hyperglycemia and insulitis in C57BL mice: Influence of background, sex and thymus. Proc Natl Acad Sci USA 79:630-634

27. Yamamoto $H$, Okamoto $H(1980)$ Protection by picolinamide, a novel inhibitor of poly(ADP-ribose)synthetase, against both streptozotocin induced depression of proinsulin synthesis and reduction of NAD content in pancreatic islets. Biochem Biophys Res Commun 94: 474-481

28. Ho C-K, Hashim SA (1972) Pyridine nucleotide depletion in pancreatic islets associated with streptozotocin-induced diabetes. Diabetes 21: 789-793

29. Schein PS, Cooney DA, McMenamin MG, Andersson T (1973) Streptozotocin diabetes: Further studies on the mechanism of depression of nicotinamide adenine dinucleotide concentrations in mouse pancreatic islets and liver. Biochemical Pharmacol 22: 2625-2631

30. Brawn K, Fridovich I (1981) DNA strand scission by enzymically generated oxygen radicals. Acta Biochem Biophys 206: 414419

31. Skidmore CJ, Davies MI, Goodwin PM, Halldorson H, Lewis PJ, Shall S, Ziaèe A-A (1979) The involvement of poly(ADP-ribose)polymerase in the degradation of NAD caused by $\gamma$-radiation and $\mathrm{N}$ methyl-N-nitrosourea. Eur J Biochem 101: 135-142

32. Sandler S, Welsh M (1982) In vitro effects of streptozotocin (SZ) on (pro)insulin biosynthesis, contents of adenine and pyridine nucleotides and oxygen uptake in mouse pancreatic islets. Acta Endocrinol (Kbh)

Received: 21 December 1981

and in revised form: 9 June 1982

Stellan Sandler

Department of Medical Cell Biology

Biomedicum

P.O. Box 571

S-751 23 Uppsala, Sweden 